TECHNICAL TRANSACTIONS 8/2018

CHEMISTRY

DOI: $10.4467 / 2353737$ XCT.18.116.8891 SUBMISSION OF THE FINAL VERSION: 27/07/2018

\author{
Przemysław Migas (iD orcid.org/0000-0003-4940-0999 \\ przemyslaw.migas@pk.edu.pl \\ Jerzy Baron (iD) orcid.org/0000-0002-6512-8983 \\ Faculty of Chemical Engineering and Technology, Cracow University of Technology
}

\title{
THE CO-COMBUSTION OF RUBBER WASTE WITH LPG FUEL IN A FLUIDISED BED REACTOR
}

WSPÓŁSPALANIE ODPADÓW GUMOWYCH Z PALIWEM LPG W PĘCHERZOWYM ZŁOŻU FLUIDALNYM

\begin{abstract}
This paper presents experimental results relevant to the thermal utilisation of rubber wastes. The investigation employed a laboratory-scale bubbling fluidised bed combustor, (BFBC) running on liquefied petroleum gas with quartz sand as the inert bed material. When rubber samples (tyre fragments) were added, the reactor temperature and flue gas concentrations of $\mathrm{CO}, \mathrm{VOC}, \mathrm{SO}_{2}, \mathrm{NO}_{x}$ and $\mathrm{HCl}$ were monitored. Tests were performed with bed temperatures of $800-1000^{\circ} \mathrm{C}$ and two different masses of the bed. It has been found that the emitted quantities of $\mathrm{NO}_{x}$ and $\mathrm{CO}$ were dependent not only on the sample mass but also on the mass (depth) and temperature of the fluidised bed and dropped whilst the bed depth was increased and its temperature was raised.
\end{abstract}

Keywords: rubber composite materials, combustion, fluidisation, LPG fuel

\section{Streszczenie}

W artykule przedstawiono rezultaty eksperymentu termicznej utylizacji odpadów gumowo-kompozytowych w pęcherzowym złożu fluidalnym zasilanym paliwem gazowym LPG. Podczas procesu dokonywano pomiaru temperatury złoża oraz analizy składu spalin jak $\mathrm{CO}, \mathrm{VOC}, \mathrm{SO}_{2}, \mathrm{NO}_{\mathrm{x}}$ oraz $\mathrm{HCl}$. Proces współspalania materiałów gumowych prowadzony był przy zmiennej masie (250 i 500g) i temperaturze złoża $800-1000^{\circ} \mathrm{C}$. Bazując na bilansie masowym węgla, przeprowadzono obliczenia kinetyczne termicznej utylizacji próbki. Stwierdzono, że ilości emitowanych $\mathrm{NO}_{\mathrm{x}}$ oraz $\mathrm{CO}$ zależą nie tylko od masy próbki, ale również od masy i temperatury złoża fluidalnego, i zmniejszają się one wraz ze wzrostem wartości wspomnianych zmiennych.

Słowa kluczowe: materiały gumowo-kompozytowe, spalanie fluidyzacja, paliwo LPG 


\section{Introduction}

The mass consumption of industrial goods is the main cause of municipal waste. Furthermore, there is a growing demand for both heat and electric power. Burning waste such as rubber or plastic, with very high fuel values, can combine waste disposal with energy production. Rubber waste consists of old vehicle tyres, transmission belts, rubber hoses, inner tubes, gaskets, etc. Therefore, by far the main source of rubber waste is the motor industry.

A vehicle tyre is a complex product containing, in addition to very durable rubber, strengthening components such as synthetic fibres and steel cords [1]. The construction of a tyre, from the point of view of the vehicle user, gives an ideal result with respect to its mechanical properties, but creates environmental problems. In Europe, around 3 million tons of old tyres (used tyre - UT) have to be disposed of annually. In 2013, around 3.6 million tons [2] had to be dealt with. Some (around 0.9 million tons) could still be used after re-trading [5]; the remainder were classified as 'end of life' ELT. In 2013, 2.7 million tons were recycled as materials or through energy recovery, which accounts for $96 \%$ of the total ELT [4]. In 2010, waste tips contained about 0.15 million tons of tyres [5]. This naturally had adverse effects on the environment, created a fire hazard and a health hazard as old tyres can serve as a breeding ground for rodents and insects [3]

A number of methods for utilising this waste have been developed, ranging from simple solutions like using whole tyres in various constructions to more advanced technologies of recycling and energy recovery [1]. As a fuel, the rubber from vehicle tyres is more homogeneous than coal. Its heat of combustion is high $\left(31.438 .8 \mathrm{MJ} \mathrm{kg}^{-1}\right)$ and the content of mineral matter does not usually exceed 3.3\% [6]. The efficiency of the combustion of a fuel normally depends on many factors such as its type and form, the concentration of the oxidiser and the temperature of the process. Parameters such as the size of the surface for heat and mass exchange or the degree of homogeneity of the fuel-oxidiser mixture depend on the combustion technology and the type of furnace employed.

Usually, the co-combustion of rubber waste takes place during the production of cement and this accounts for $91 \%$ of the tyres utilised during energy recovery [4]. Using tyres as an alternative to coal makes it possible to lower the costs of cement production. One of the advantages is that rubber provides the necessary sulphur as well as, for example, certain noncombustible components, such as metal oxides, the presence of which improves the quality of the clinker obtained.

The tyres are fed to the furnace either whole or fragmented as tyre derived fuel (TDF). Since the residence time of tyres or TDF in an environment is short where the prevailing temperature is significantly higher than $1,500^{\circ} \mathrm{C}$ it is completely consumed[7], while the emissions of dioxins and the products of incomplete combustion remain very low. However, cement kilns are few and far between which increases the costs of transportation. Furthermore, tyres are completely consumed in a cement kiln, so that even partial recovery of the steel elements present in the tyres is impossible. In addition to utilisation in rotary cement kilns, TDF can be used in heat and power plants, e.g. in moving grate furnaces. This makes it possible to utilise tyres of various sizes, with relatively low operational costs. Complications 
arising during the process are usually associated with the limited availability of the oxidiser necessary to assure the complete combustion of the waste[8].

Installations employing fluidised beds are free from this problem and their use in the thermal utilisation of rubber wastes has been discussed in many publications. For example, Chyang et al. used a rotating bed to burn tyres and other forms of rubber waste $[9,10]$ They found that if the combustor is supplied with rubber fragments that are uniform in size, the increased frequency with which the fuel is fed in leads to lower $\mathrm{CO}$ emissions and a higher mean bed temperature. In addition, they noted that if an additional stream of air was directed to the freeboard, this improved the conversion of the volatile products of the incomplete decomposition of hydrocarbons and its suitable method of introduction and feed rate can help in the formation of horizontal eddies, facilitating the efficient removal of small dust particles. Another example of the use of FBC technology is the co-combustion of rubber waste with coal. Alvarez et al. [6] and Calle' $n$ et al. [11] found that an increased rubber content in a solid fuel mixture leads to higher emissions of aromatic compounds and an increased zinc content in the solid products from the process, particularly in the form of volatile ash. Fluidised bed combustors, FBCs, should be suitable for burning tyre wastes. The disadvantages are the costs, both operational and those associated with fragmenting the material. In this respect, the effectiveness could be improved by, for example, burning larger batches of the waste. However, the main advantage of the method is its flexibility, since it offers the possibility of utilising not only combustible solids, but also liquids or gases. Another factor is the possibility of limiting noxious emissions. Thus, FBC installations can be used to burn various other forms of waste[12], such as polymers[13, 15] biomass, [16], [18] and electronic waste[23] in addition to rubber.

The literature suggests that the problems associated with the batch method of burning rubber can be avoided if the fragmented waste is continuously supplied to a FBC running on gaseous fuel. This stabilises the temperature and the continuous combustion of the gas and ensures the presence of sufficient concentrations of free radicals, which play a crucial role in the attack on the volatile products of the thermal decomposition of both rubber volatiles and solids. However, basic information relevant to this type of approach to burning rubber waste appears to be absent. The present work was undertaken to elucidate the thermal decomposition of rubber during combustion, to study the composition of the flue gases and its dependence on the type of rubber waste burned and on the temperature and the effective height of the fluidised bed.

\section{Materials, Apparatus, Methods}

The experiments were carried out using a laboratory-scale bubbling fluidised bed reactor described in detail elsewhere[24]. It consisted of a cylindrical quartz glass tube, 98 $\mathrm{mm}$ in diameter and $500 \mathrm{~mm}$ long, resting on a distributor plate made of Cr-Ni steel, with approximately 433 uniformly distributed holes (diameter $=0.6 \mathrm{~mm}$; free area $=1.6 \%$ ). The bed material used was quartz sand, 250 or $500 \mathrm{~g}$, particle size $300-385 \mu \mathrm{m}$, giving a stationary bed depth of 2.2 or $4.5 \mathrm{~cm}$, depending upon the experimental condition At $20^{\circ} \mathrm{C}$, the air supply rate was $1.92 \cdot 10^{-3} \mathrm{~m}^{3} \mathrm{~s}^{-1}$, and the supply rate of LPG was $3.42 \cdot 10^{-4} \mathrm{~m}^{3} \mathrm{~s}^{-1}$. The two 
streams were mixed with before entering the reactor (air excess was 40\%). The temperature inside the reactor was monitored using two shielded $\mathrm{Ni}-\mathrm{NiCr}$ thermocouples, mounted at 20 and $50 \mathrm{~mm}$ above the distributor. Readings from these were registered at a frequency of $10 \mathrm{~Hz}$. The flue gases were analysed using a FTIR Gasmet ${ }^{\mathrm{tx}}$ DX-4000 analyser, the time of analysis was approximately $8 \mathrm{~s}$. A schematic diagram of the apparatus is shown in Fig. 1.

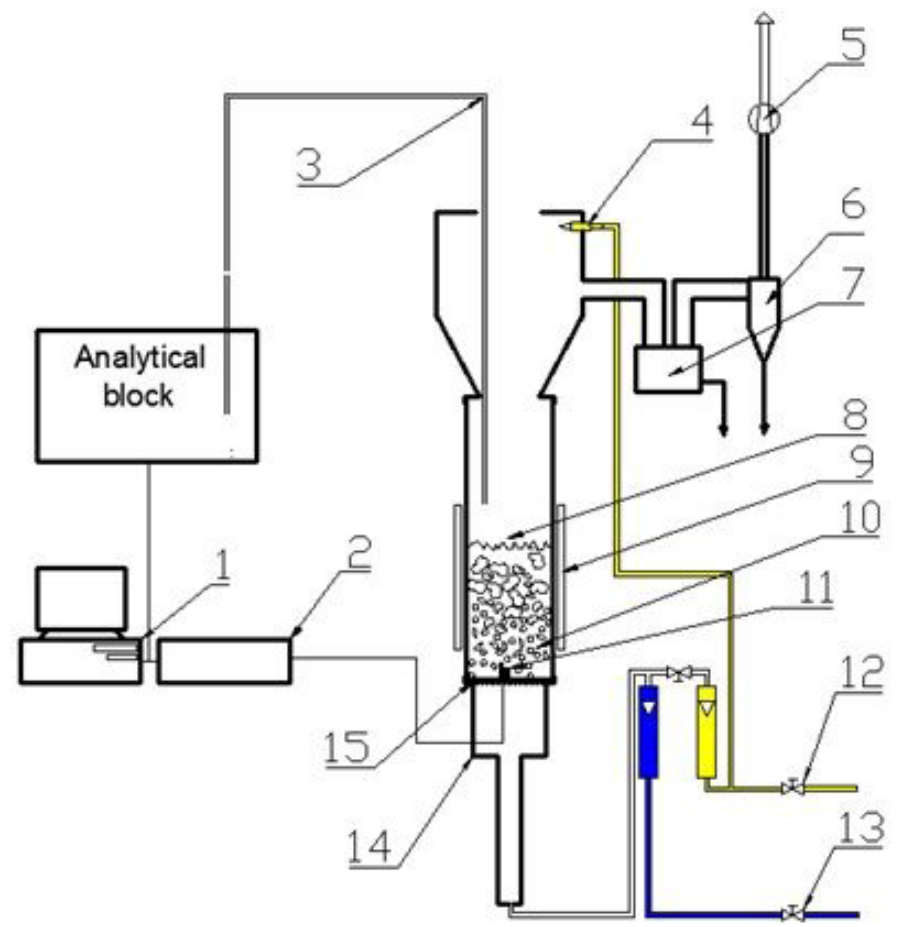

Fig. 1. Experimental arrangement - schematic representation

1 - computer storing chemical analysis quantities and temperature signals, $2-\mathrm{A} / \mathrm{D}$ convertor for thermocouple signals, 3 - heated probe for sampling the flue gases, 4 - pilot flame, 5 - exhaust fan,

6 - cyclone, 7 - ash trap for coarser particles, 8 - freeboard space, 9 - movable radiation shield, 10 - bubbling bed, 11 - thermocouples, 12 - fuel supply valve, 13 - air supply valve, 14 - plenum chamber, 15 - flat, perforated metal plate

In the course of the experiments, three types of tyre rubber were tested: samples with synthetic fibres (with a polyester coating) taken from the sides of tyres, fragments with steel reinforcement and fragments with chlorinated copolymers. The sample mass used was up to $4 \mathrm{~g}$. Table 1 shows the three types of sample and gives their $\mathrm{C}, \mathrm{H}$ and $\mathrm{N}$ contents, determined by the combustion method, using a Perkin Elmer 2400 instrument (detection is conducted using an IR detector).

The results obtained for the $\mathrm{C}, \mathrm{H}$ and $\mathrm{N}$ content of the samples investigated were comparable with the analytical results provided by other investigators $[8,19,20,21,22]$. The carbon in the copolymer was lower and amounted to $70-75 \%$ of that in the rubber samples while the nitrogen content was 3-4 times higher. 
Table 1. Samples of the wastes investigated and their analytical content of C, H and N, mass \%
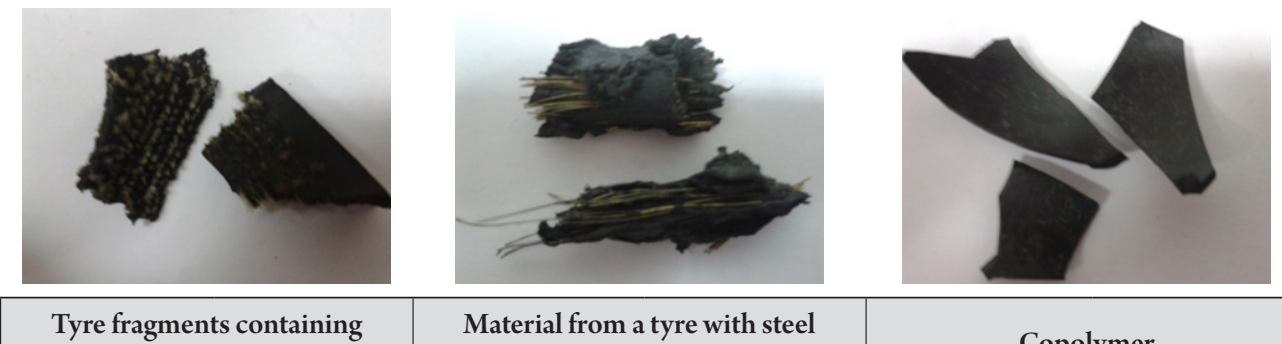

\begin{tabular}{|c|c|}
\hline C & 85.1 \\
\hline $\mathrm{H}$ & 7.8 \\
\hline $\mathrm{N}$ & 0.3 \\
\hline
\end{tabular}

Material from a tyre with steel reinforcement

\section{Results and discussion}

\section{a) Visual observations}

Single Samples of car tyre material were added to a fluidised bed combustor operating at a stable temperature. Rapid fragmentation of the sample started immediately and blue flames appeared inside the bed (Fig. 2).

Because of the rapid formation of combustible volatiles, they may remain unburned inside the bed. Since the position of the sample and later the positions of its fragments in the bed were constantly changing, the residence time of the volatile pyrolysis products inside the bed was not always sufficient for the reaction to finish. This led to transient diffusion flames also appearing above the bed surface, a typical flame lasted for around 0.1s [13]. It was also noted that not all gas bubbles ignited on reaching the bed surface. This was probably because the time spent by the gases inside the bubbles that failed to ignite was less than the induction period for ignition [25]. It was also possible that the composition of the gases inside some bubbles was outside the ignition limits for the mixture (i.e. insufficient combustibles or lack of oxidant). The flames above the bed gradually died out whilst inside the bed, the remaining carbonaceous solid particles were slowly consumed in a heterogeneous combustion process. The bright burning particles could be clearly seen moving inside the bed in a similar manner as during the combustion of coal (Fig. 2). The VOC formation and their combustion had a stochastic character, consistent with the intensive movement of fuel particles inside the bed. The sinking down of a sample inside the bed and its remaining there would be possible if its density is greater than the local mean density of its surroundings [14]. This might occur with sand grains sticking to the sample, increasing its effective size and thus the apparent mean density. 


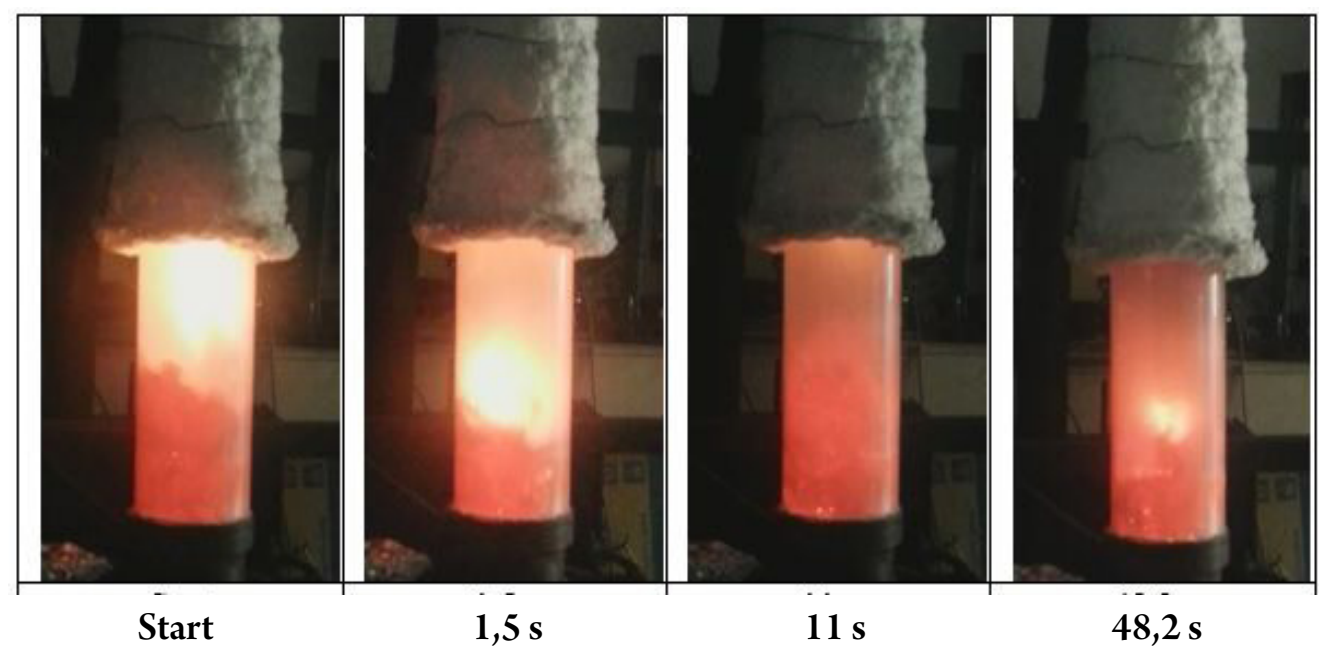

Fig. 2. Selected frames from a film documenting selected stages of the experiment of copolymer combustion

\section{b) Chemical Analysis of the flue gases}

When a sample of tyre material was dropped on the surface of the hot fluidised bed, there was always a sharp decrease in the $\mathrm{O}_{2}$ concentration in the off gases and peaks appeared in the concentrations of the reaction products, including VOC and $\mathrm{CO}$ (Fig. 3), resulting from the pyrolysis of the sample and the combustion process.
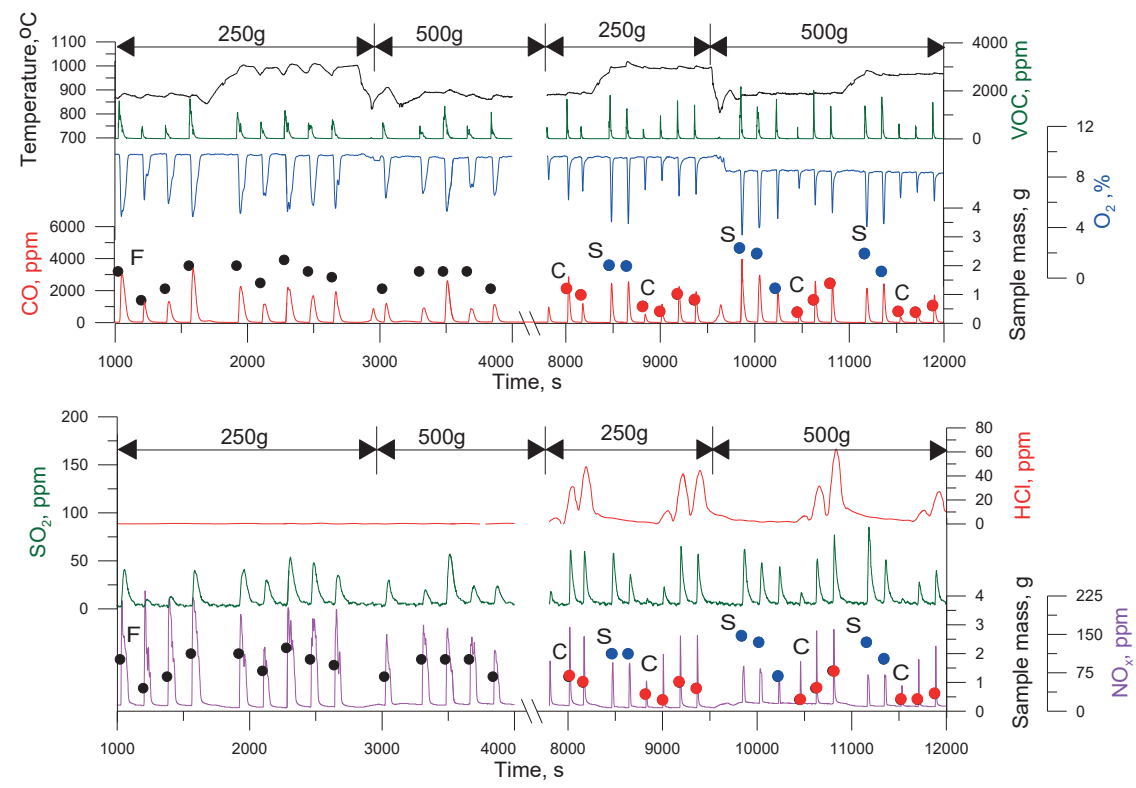

Fig. 3. Selected experimental results (sample F - with synthetic fibre, $\mathrm{S}$ - with steel reinforcement, $\mathrm{C}$ - the copolymer; dots show the sample mass 
Changes in the concentrations of $\mathrm{CO}$ and VOC were linked and the width of the VOC peaks was less than that of the other products. This indicates that the VOC emission drops in the further stages of sample decomposition e.g., after the burning of solid residues (char particles). $\mathrm{HCl}$ and $\mathrm{SO}_{2}$ emission depends on the mass and sample type, whereas for the VOC and $\mathrm{NO}_{\mathrm{x}}$ depends also on the height and temperature bed. The maximum values of nitrogen oxide varied within the range of 50-250 ppm, and they did not exceed $400 \mathrm{ppm}$ for sulphur dioxide. $\mathrm{HCl}$ was detected only during copolymer combustion, and the concentration changed within the range of 5-80 ppm.
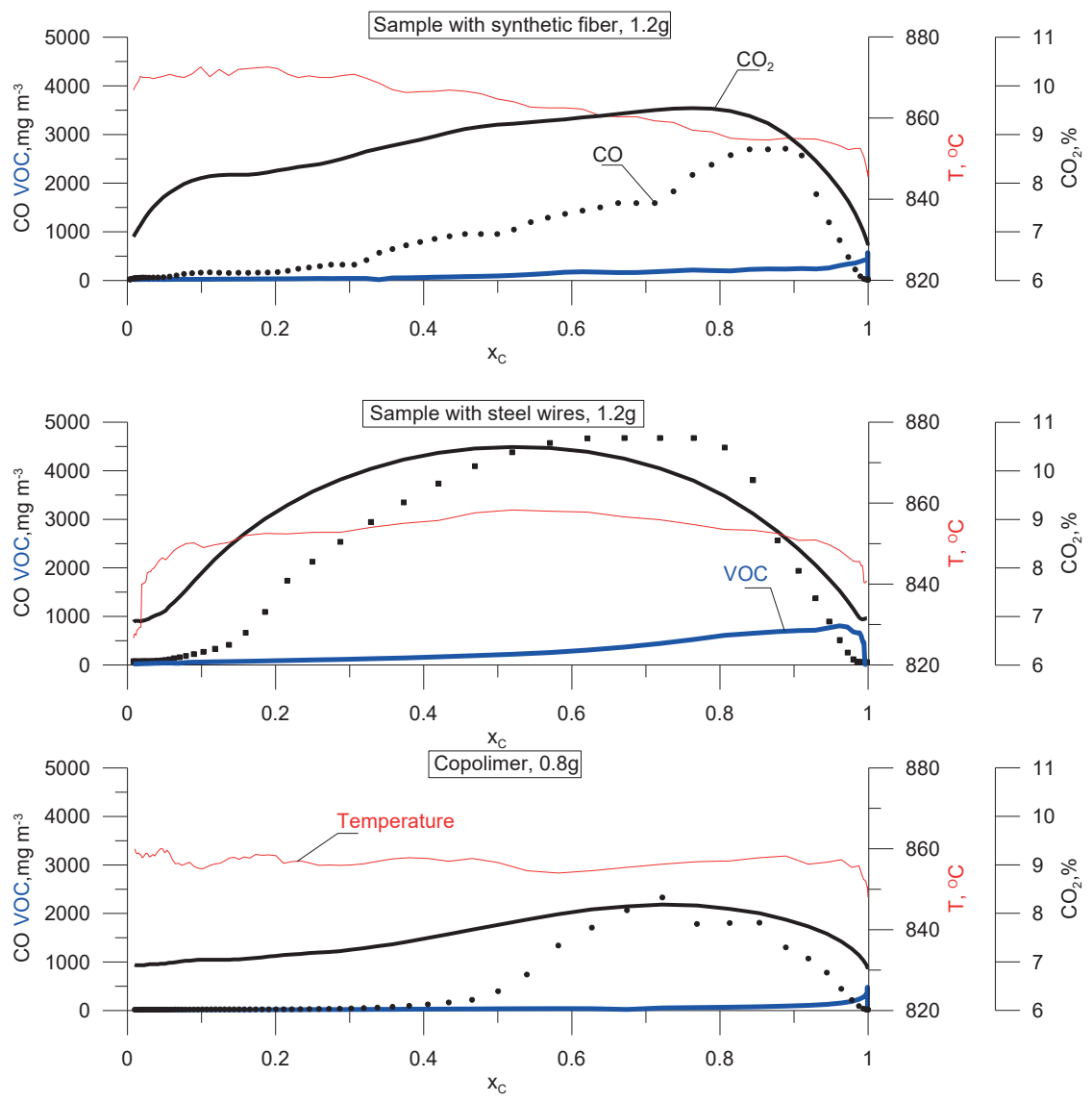

Fig. 4. Selected experimental results as a function of a carbon mass fraction (remaining in the combustion zone)

Rapid emissions of VOC may be recorded immediately samples are introduced to the hot bed. The peak level of VOC is twice as high for the sample with steel reinforcement than for the other samples. During the latter stages of VOC decomposition VOC concentration drops, which may indicate that the thermal decomposition of the samples is slower than the VOC oxidation process. 
CO concentration (Fig. 5) decreases with increases in temperature; this is certainly attributed to the oxidation rate. The ignition of combustible gas products (in the gas-air bubble) of rubber degradation is possible at a certain bed height only if the flammability limit and proper temperature is maintained inside the bubble. If the VOC emission (caused by the rubber sample devolatilisation) is located near the bottom of the FBC while the bed temperature and air velocity remain constant, a higher bed enables a longer VOC residence time in the reaction zone. Therefore, if the bed porosity is similar, CO concentration decreases with increases to the bed mass. It was also observed that the presence of chlorine in the incinerated sample increases $\mathrm{CO}$ emission. Chlorine may behave like a flame retardant - gaseous $\mathrm{HCl}$ (a product of combustion) reacts with $\mathrm{H}$. and $\mathrm{OH}$. radicals which play an important role in hydrocarbon chain decomposition.

$$
\begin{gathered}
\mathrm{H} \cdot+\mathrm{HCl}=\mathrm{H}_{2}+\mathrm{Cl} . \\
\mathrm{HO}+\mathrm{HCl}=\mathrm{H}_{2} \mathrm{O}+\mathrm{Cl} .
\end{gathered}
$$
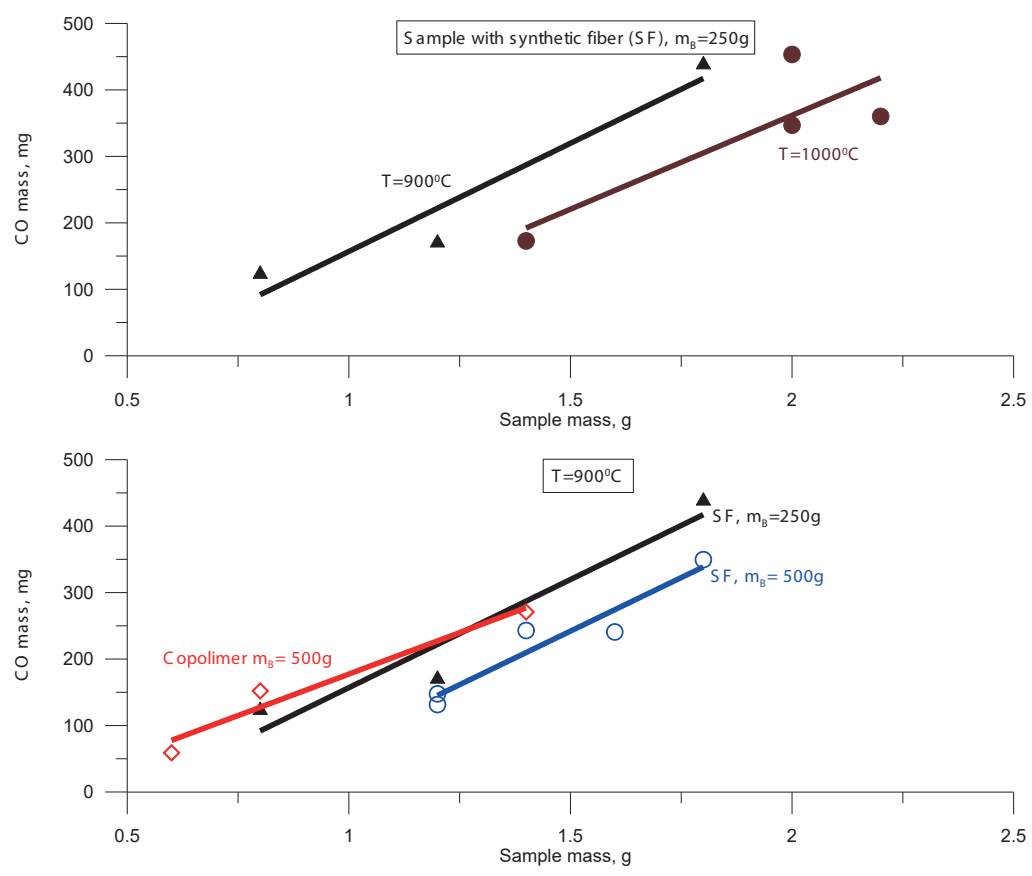

Fig. 5. Selected parameters influence on $\mathrm{CO}$ emission

$\mathrm{NO}_{\mathrm{x}}$ emission (Fig. 6) decreases as the bed temperature increases. It is possible that two parallel processes occur. The first is that the pyrolysis rate rises as the bed temperature increases, which causes more intensive $\mathrm{VOC}$ emissions. As a consequence, $\mathrm{NO}_{\mathrm{x}}$ reduction may occur in the gas layer surrounding the rubber sample (in processes such as re-burning) [27] [28]. An increasing rising bed temperature also causes the VOC and CO oxidation rate to increase resulting in a lack of oxygen in the reaction environment. $\mathrm{NO}_{\mathrm{x}}$ emission (similar to $\mathrm{CO})$ decreases with a higher bed mass. This phenomenon is connected with an increasing gas 
residence time, which causes higher $\mathrm{CO}$ and VOC conversion. It may also be observed that the smallest $\mathrm{NO}_{\mathrm{x}}$ concentration is measured during copolymer combustion, which can also be explained by the $\mathrm{CO}$, and $\mathrm{VOC}$ reductive effect.

Comparison between $\mathrm{CO}$ and $\mathrm{NO}_{x}$ concentration didn't prove the diverse proportionality between concentrations of those two gases, as suggested by Duan's study [26]. Duan used rubber balls during the combustion process. During our research, additional effects may occur, such as the influence of synthetic fibre combustion, which may disturb the $\mathrm{CO}$ and $\mathrm{NO}_{\mathrm{x}}$ concentration relationship.
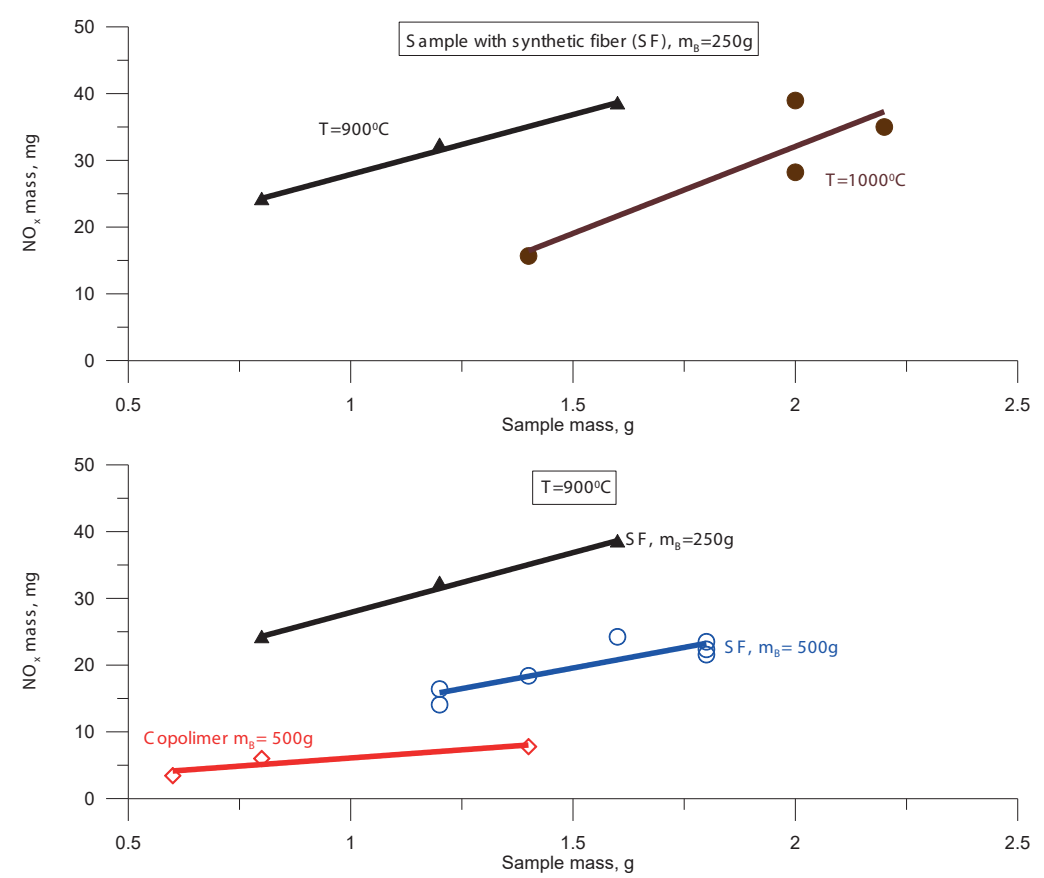

Fig. 6. The influence of selected parameters on $\mathrm{NO}_{\mathrm{x}}$ emission

In Fig. 7, the comparison that was made between the co-incineration and incineration processes (with and without additional LPG fuel) is presented for the $0.4 \mathrm{~g}$ rubber sample with synthetic fibres. Changes in the $\mathrm{NO}_{x}$ and $\mathrm{CO}$ concentrations in the two processes are presented in Fig. 7 (oxygen concentration during co-combustion was around 10\%). When additional fuel wasn't supplied, $\mathrm{CO}$ concentration was around $50 \mathrm{ppm}$ whilst during co-combustion, it reached around 2,500 ppm.

Drops in the level of CO concentration are certainly linked with a higher rates of burning with $\mathrm{O}_{2}$ concentration. Nitrogen oxide synthesis is possible not only from the fuel's nitrogen but also from the air if the temperature is high enough. Thus, $\mathrm{NO}_{\mathrm{x}}$ emission during co-incineration is higher than it is from combustion. Which is attributed to the presence of $\mathrm{CHi}$ radicals that are formed during the combustion of hydrocarbons [29] 

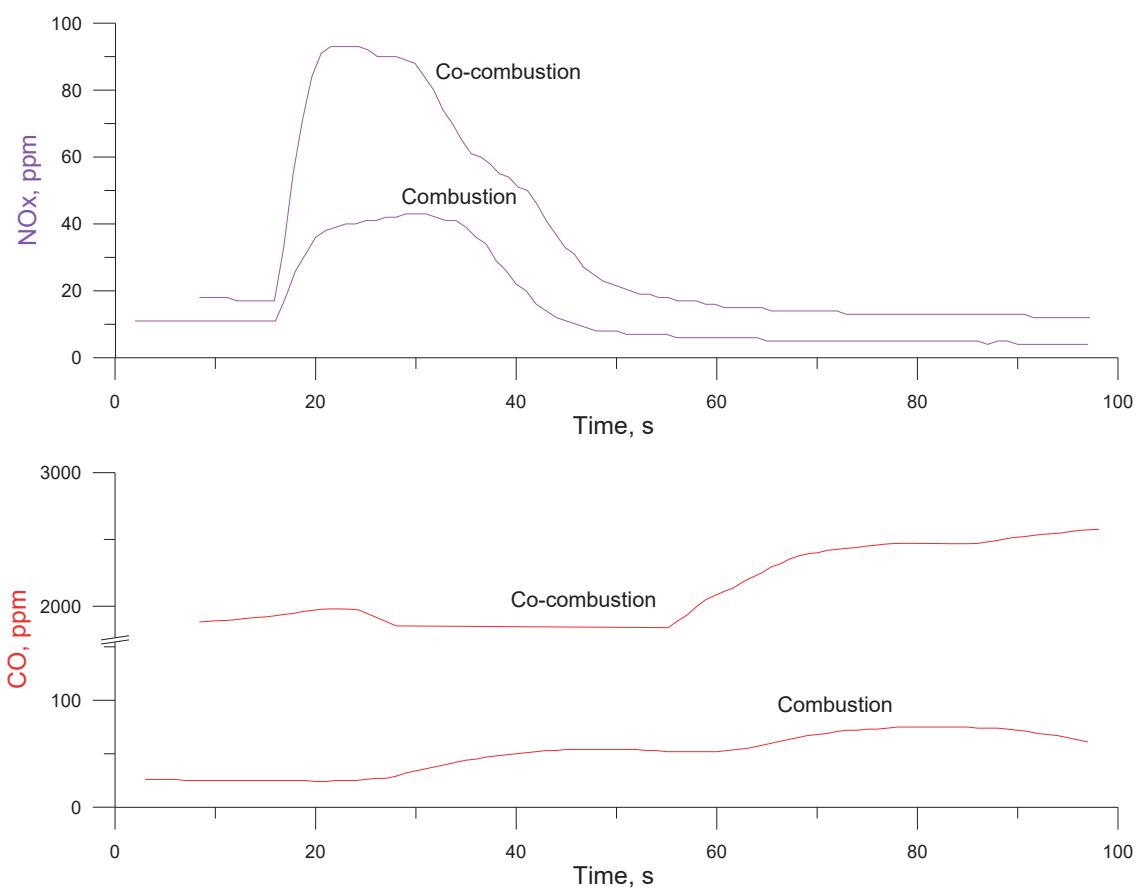

Fig. 7. Comparison between $\mathrm{CO}$ and $\mathrm{NO}_{x}$, concentration during combustion and co-combustion processes (sample with synthetic fibre)

The recovery of steel elements may be important from the economic point of view due to this being a special steel of high quality. The long residence time of steel elements at high temperature and the very corrosive environment of $\mathrm{HCl}$, and $\mathrm{SO}_{2}$ gases causes huge deterioration of its surface and internal structure (Fig. 8). From the material recovery point of view, it's important to limit the steel element residence time to the necessary minimum.

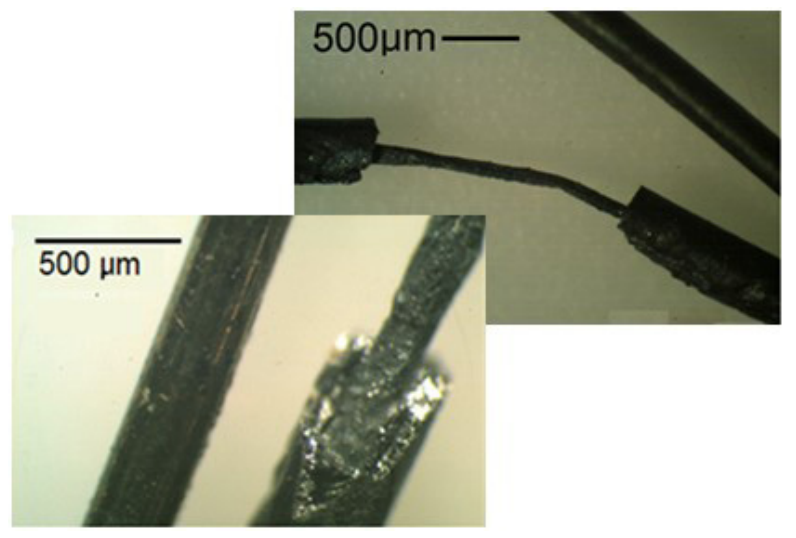

Fig. 8. Steel elements before and after being introduced to the reactor $\sim 1 \mathrm{~h}$ residence time in the reaction zone 


\section{Conclusions}

During the incipient stage of rubber composite material combustion (intensive rubber devolatilization), high emission of VOC and flame above the bed is observed. Next, the residual char particles are after-burned. Flame occurrence was very irregular; this may be linked to the inflammable character of the gas inside the bubble, the stochastic rubber sample movement, and the subsequent changeable residence time of gaseous products and the time of bubble heating (time ignition initiation must be exceeded in order for combustion to occur in the bed).

During the combustion of the copolymer and the sample with steel elements, the VOC emission is higher than from the sample with synthetic fibres. In the copolymer, this is attributed to the presence of chlorine, while in the sample with steel elements, it may be caused by the thermal degradation rate growth (the presence of steel elements causes an intensification of the heat transfer to the interior of the sample).

The recovery of steel elements may be important from the economic point of view due to this being a special steel of high quality. However, due to high temperature corrosion and the presence of $\mathrm{HCl}$ and $\mathrm{SO}_{2}$ in the reaction zone, it is necessary to limit the steel elements residence time to the minimum that is necessary.

\section{References}

[1] Erich F., Erman B., Mark J., The science and technology of rubber, Elsevier, 2005.

[2] The Waste \& Resources Action Programme - The Composition of a Tyre: Typical Components Project code: TYR0009-02,

[3] http://www.wrap.org.uk/sites/files/wrap/2\%20-\%20Composition\%20of\%20a\%20 Tyre\%20-\%20May\%202006.pdf (access: 08.03.18).

[4] UNEP/CHW.10/6/Add.1/Rev.1 Technical guidelines on the environmentally sound

[5] co-processing of hazardous wastes in cement kilns, http://www.basel.int/Portals/4/ Basel\%20Convention/docs/pub/techguid/cement/tg-cement-e.pdf(access: 12.03.18).

[6] ETRMA, End-of-life Tyre Report 2015,

[7] http://www.etrma.org/uploads/Modules/Documentsmanager/elt-report-v9a---final.pdf (access: 08.03.18).

[8] End of life tyres. A valuable resource with growing potential 2011 edition,http:// www.etrma.org/uploads/Modules/Documentsmanager/brochure-elt-2011-final.pdf (access: 12.03.18).

[9] Bautista D., Carmen M., Jul C., Jul R., Mastral A.M., Rodríguez A., Rodríguez M.A., $A F B C$ of coal with tyre rubber Influence of the co-combustion variables on the mineral matter of solid by-products and on Zn lixiviation, "Fuel", 106/2013, 10-20.

[10] Scrap Tire Management Council, The Use of Scrap Tires in Rotary Cement Kilns, https://rma.org/wp-content/uploads/cement_kiln_report.pdf (access: 12.03.18) .

[11] Annus J., Jelemenský L., Juma M., Koreňováv Z., Markoš J., Pyrolysis and combustion of scrap tyre, "Petroleum \& Coal" 48/2006, 15-26. 
[12] Chyang C., Ho J.A., Shang S., Teng H., Characterization of Waste Tire Incineration in a Prototype Vortexing Fluidized Bed Combustor, "Journal of the Air \& Waste Management Association", 47/1997, 49-57.

[13] Duan F., Chyang C., Hsu S., Tso J., Combustion behavior and pollutant emissions of batch fluidized bed combustion, "Journal of the Taiwan Institute of Chemical Engineers" 44/2013, 1034 - 1038.

[14] Calle'n, M.S. Mastralm A.M., Garcı'a T., Fluidized Bed Combustion (FBC) of Fossil and Nonfossil Fuels. A Comparative Study, "Energy \& Fuels” 14/000, 275-281.

[15] Chirone R., Scala F., Fluidized bed combustion of alternative solid fuels, "Experimental Thermal and Fluid Science" 28/2004, 691-699.

[16] Baron J., Bulewicz E.M., Kandefer S., Pilawska M., Żukowski W., Hayhurst A.N., The combustion of polymer pellets in a bubbling fluidised bed, "Fuel", 85/2006, 2494-2508

[17] Davidson J.F., Dennis J.S., Hayhurst A.N., Rees A.C., The rise of a buoyant sphere in a gasfluidized bed, "Chemical Engineering Science" 60/2005, 1143-1153.

[18] Burgess F., Lloyd P.D.W, Fennell1 P.S., Hayhurst A.N., Combustion of polymer pellets in a bubbling fluidised bed, "Combustion and Flame", 158/2011, 1638-1645

[19] Khan A., Jong W., Jansens P.J, Spliethoff H., Biomass combustion in fluidized bed boilers: Potential problems and remedies, "Fuel processing technology", 90/2009, 21-50.

[20] Fytili D., Zabaniotou A., 4, "Renewable and Sustainable Energy Reviews", 12/2008, $116-140$.

[21] Okasha F., Zaater G., El-Emam, S., Awad M.., Zeidan E., Co-combustion of biomass and gaseous fuel in a novel configuration of fluidized bed: Combustion characteristics, "Fuel", 133/2014, 143-152.

[22] Cabrero M.A., Caballero B., Chomon M.J., Laresgoiti M.F., Rodriguez I., Torres A., Pyrolysis of scrap tyres, "Fuel Processing Technology" 72/2001, 9-22.

[23] Kim D., Kim J., Lee J., Lee J., Pyrolysis of waste tires with partial oxidation in a fluidized-bed reactor, "Energy", 20/1995, 969-976.

[24] Chirone R., Salatino P., Senneca O., A fast heating-rate thermogravimetric study of the pyrolysis of scrap tyres, "Fuel", 78/1999, 1575-1581.

[25] Canito J., Encinar J., González J., Rodríguez J., Pyrolysis of automobile tyre waste. Influence of operating variables and kinetics study, "Journal of Analytical and Applied Pyrolysis", 58/2001, 667-683.

[26] Woynarowska A., Witold Żukowski W., Żelazny S., Thermal treatment of electronic waste in a fluidised bed and chemical digestion of solid products, "Waste Management \& Research", 34/2016, 605-618.

[27] Baron J., Bulewicz E.M., Zabagło J., Żukowski W., Propagation of Reaction Between Bubbles with a Gas Burning in a Fluidised Bed, "Flow, Turbulence and Combustion" 88/2012, 479-502.

[28] Żukowski W., A simple model for explosive combustion of premixed natural gas with air in a bubbling fluidized bed of inert sand, "Combustion and Flame" 134/2003, 399-409. 
[29] Chyang C.S., Duan F., Hsu SH., Tso, J., Combustion behavior and pollutant emissions of batch fluidized bed combustion, "Journal of the Taiwan Institute of Chemical Engineers", 44/2013, 1034-1038.

[30] Ho L., Maly P., Payne R., Zamansky V., Alternative fuel reburning, "Fuel” 78/1999, 327-334.

[31] Smoot L.D., Hill S.C., Xu H., NOx Control Through Reburning, "Progress in Energy and Combustion Science", 24/1998, 385-408.

[32] Fenimore C.P., $13^{\text {th }}$ Symposium (Int.) on Combustion, 13/1971, 373-380. 